\title{
CENTRAL AMERICAN RIVERS AS SITES OF COLONIAL CONTESTATION
}

In the introduction to Troubled Waters: Rivers in Latin American Imagination, Elizabeth Pettinaroli and Ana María Mutis provide a historical overview of the many ways in which rivers in Latin American literature constitute "a distinctive space for the symbolic negotiation of the critical consciousness that shapes collective memories and subjectivities" as well as a "locus for the literary exploration of questions of power, identity, resistance, and discontent" (Pettinaroli and Mutis 2013: 5). Scholars of Latin American Literature have observed a variety of ways in which rivers have helped shape the Latin American literary imaginary. To name just a few, they have allowed scholars to place the writings of Alexander von Humboldt in dialogue with contemporary environmental thought (Marcone 2013: 89), have been the focus of early $20^{\text {th }}$ century literary projects related to nationalism (Anderson 2013: 122), have been employed as vehicles "to convey disenchantment with the ideas of progress and globalization" (Pettinaroli and Mutis 2013: 11) as well as "countercurrent discourses" that offer a reevaluation of colonial and neocolonial endeavors (Kressner 2013: 191). As highlighted throughout Troubled Waters, rivers have been the object of the colonial gaze in Latin American literature from Christopher Columbus's letters to the Spanish monarchs to contemporary representations of hydroelectric dams (Pettinaroli and Mutis 2013: 1, 13).

With regard to Central American cultural production, for both historical and artistic reasons, the imagery of rivers frequently
Adrian Taylor Kane Boise State University USA

(iD 
plays an important role in works from and about the region's civil wars of the 1960s-1990s. In an effort to highlight a few important examples of the presence of rivers in Central American literature and film of the civil war period, in the present essay I analyze Salvadoran director Luis Mandoki's 2004 film Voces inocentes (Innocent Voices), fellow Salvadoran Mario Bencastro's 1997 novella "Había una vez un río" ("Once Upon a River"), and Nicaraguan-Salvadoran Claribel Alegría's 1983 testimonial poem "La mujer del Río Sumpul" ("The Woman of the Sumpul River"). These works, I argue, are examples of the ways in which Central American rivers often were portrayed as "deathscapes" that are historically marked by statesponsored violence against Salvadoran citizens (Maddrell and Sidaway 2010: 4). As sites of massacres of unarmed civilians and armed conflicts between the Salvadoran military and the revolutionary Farabundo Martí National Liberation Front (FMLN), the rivers in these works become ground zero in the Salvadoran government's oppression of social movements aimed at reforming the nation's neocolonial political and economic structures. Having established the centrality of rivers as deathscapes in Innocent Voices, "Once Upon a River," and "The Woman of the Sumpul River," I will then turn my attention to Guatemalan author Arturo Arias's 2015 novel El precio del consuelo (translated here as The Price of Comfort), which also features a river as the site of state-sponsored violence against rural citizens during the civil war period. In contrast with the Salvadoran works, however, Arias's novel also highlights issues of environmental justice related to the use of rivers in Central America that continue to plague the region to date. In the present essay, I thus argue that these works are compelling representations of the ways in which rivers have become sites of contestation between neocolonial and decolonial forces in Central America.

THE IMAGE OF THE RIVER IN INNOCENT VOICES

In Luis Mandoki's 2004 film Innocent Voices, the loss of innocence is a central theme. Based on co-writer Óscar Torres's childhood in Cuscatancingo, El Salvador, the film is set in the final years of the Salvadoran civil war and focuses on the forced recruitment of twelve-year old boys into the Salvadoran military to combat the revolutionary guerillas of the FMLN. Released twelve years 
after the end of the conflict, Mandoki's film serves as an ex post facto denunciation of the Salvadoran army's policy during the war as well as a form of resistance to military recruitment of children around the globe. At several key moments of the plot in Innocent Voices, the image of the San Antonio river figures prominently. The film begins in slow motion as the protagonist Chava and his friends are led down a muddy road, through the rain, at gunpoint by Salvadoran soldiers. Although the viewer does not learn so for certain until the end of the film, they are being led to the river to be executed. The story is an analepsis told from Chava's perspective that returns to this moment at the end of the film.

The river is initially portrayed as a place of recreation associated with the innocence of youth. Early in the film, Chava and his schoolmates playfully wrestle at the river's edge, an image that aligns with conventional symbolic uses of rivers in Latin America. As Mark D. Anderson observes, "drinking and immersion in a river's waters have a long genealogy as symbols of communion and baptism [...]. In overwhelmingly Catholic, postcolonial Latin America, national waters took on pseudo-religious connotations of purity, communal integration, rebirth, and emergence" (2013: 118). The image of joyful innocence is disrupted, however, when the boys spot soldiers from the Salvadoran army marching into their village with machine guns slung over their shoulders. This scene is important because it begins the pattern of events throughout the story in which the children's youthful naiveté is stripped away by the war that is ravaging their community. Indeed, this becomes the film's central theme when the military marches into the local schoolyard, removes the twelve-year old boys from their classes, and sends them off in a truck to join the Salvadoran army.

The loss of innocence motif is continued when the film returns to the river where the four boys who play there at the beginning of the film are now in their underwear throwing rocks into the river after going for a swim. In this scene, however, it is their friend and former classmate Antonio who appears in military camouflage with his automatic rifle in hand and interrupts their games by firing a shot into the air. Their invitation for Antonio to join

1. In my email interview of Torres he confirmed that it is the San Antonio River depicted in the film. 
them in throwing stones into the river presents a stark contrast with the stories he tells them about being trained by gringos and ambushing guerrillas.

The process of Chava's traumatic loss of childhood to the war is complete by the end of the story. When the young protagonist and his friends manage to evade recruitment, they leave the protection of their families, and escape into the night to join the guerrilla forces. In doing so, they unintentionally lead a group of soldiers to the guerrilla camp in the jungle. Chava and his friends are captured, and the film returns to the opening shot of the boys walking at gunpoint through the rain. It is not until this point, however, that the viewer learns for certain that in the initial shot the boys are being led to the river to be executed.

Chava and his friends kneel down at the river's edge. Two are shot in the back of the head. Just before Chava is about to be killed, a group of guerrillas emerges from the trees and engages the soldiers in a firefight. Chava escapes and runs home to find his village incinerated. Bloody cadavers are strewn across the river and, above, Chava's cognitively impaired friend Ancha hangs from a noose with a bullet hole in his forehead. Once again, the conventional use of rivers as symbols of life, innocence, and purity has been turned on its head. What was once Chava's playground has been converted into a burial ground.

By memorializing the river through film as a site where innocent

Rivers of the Americas lives were taken, it becomes what Avril Maddrell and James D. Sidaway describe as a deathscape, "a place associated with death, but also as a memorial site with deep symbolic meaning" (2010:4). ${ }^{2}$ As Maddrell and Sidaway argue:

death and dying are intensely anchored in space and place. Death and dying draw attention to the meanings that we invest in space and place, in as much as spaces and places associated with death and dying to evoke the deepest memories and to stir an intensity of emotions is evidence of the power of place, and is a reminder that the very nature of our meaningful experience with place is fundamentally anchored in emotions, not functions. At the same time, the process

2. Tricia Cusack discusses the related concept of "riverscapes" in Riverscapes and National Identities (2019). 
and experience of death and dying is intensely place-based, deeply associated as they are with particular sites and locations. (xv)

For co-writer Oscar Torres, constructing memory is a crucial function of film-"to remind ourselves that tragedy exists in this world, and that if we are not conscious enough, not educated enough, not present enough, if we forget that the chance that it will happen again is too present, it is a dangerous thing to forget" (Torres 2015: 10:06). Despite having received death threats for the film's historical content, he also recalls that when he returned to El Salvador upon the film's launch, "A woman there said to me, 'I thank you so much for this film because we have these memories, but we are told every day that it didn't happen'"' (Mann 2005: 5:58). Both the threat of murder for revealing the oppressive nature of the Salvadoran military during the war and the continual attempt to suppress historical truths about the war are examples that support Edurne Portela's contention that the act of remembering in Latin American cultural production is often "set against oblivion and for justice [...] as a strategy to avoid the repetition, to denounce the violation of human rights, and to pay tribute to the victims" (161). This is precisely the function of Innocent Voices, which, through Chava's story, condemns the military's recruitment of children, refuses to allow this episode of history to be forgotten, and makes a powerful plea for the end of such practices around the world. The contrasting imagery of the river plays a critical role in the film's reconstruction of memory.

\section{MARIO BENCASTRO'S "ONCE UPON A RIVER"}

The contrasting imagery of the river in Innocent Voices as a symbol of both the innocence associated with childhood and the suffering of a country ravaged by political murder and guerrilla warfare is also present in Salvadoran author Mario Bencastro's novella "Once Upon a River," which interweaves imagery of rivers with testimonial accounts. In Bencastro's own words, his story combines "fiction, historical reality, superstition, and testimony" (The Tree of Life 110). Like Innocent Voices, it is a bildungsroman about an adolescent boy who is thrust into adulthood by the violence of civil war. The story begins with a brief introductory section 
in which the river is established as a source of life for the valley around it. The plot develops with many of the conventions of a typical coming-of-age story by portraying the protagonist Tomás's relationships with his high school classmates and his growing affection for his girlfriend Esperanza. but the historical context forbids the possibility of the story focusing solely on these aspects of his development. His father is murdered by the Salvadoran army while working at the local cooperative farm, his sister leaves home to join the guerrilla movement, his Spanish teacher is assassinated in the schoolyard, and he and Esperanza narrowly escape death at the hands of the general who terrorizes their village on a daily basis.

The story's climax arrives when Tomás returns home from school one day to find the entire village fleeing towards the river. The narrator describes the scene:

Helicopters flew over the trees, vomiting bombs and bullets. Homes were devoured by flames. The stampede finally reached the banks and the people threw themselves into the water. but the bullets were accurate. The river was incapable of protecting them. Tomás and Esperanza were left locked in an embrace, near a large rock, sprayed with bullets. $(101)^{3}$

In contrast to the coming-of-age narrative in Innocent Voices, where defining events in the protagonists' development occur by a river, in Bencastro's novella, Tomás is murdered in the river and robbed

Rivers of the Americas of the opportunity to complete his transition into adulthood. The symbolic meaning of the river has now shifted from life to death.

The fragments of text that follow the narration of Tomas's death are structured as testimonials and are based on the accounts of survivors compiled by journalists in the brochure "Sumpul" and by investigators from the United Nations Truth Commission for El Salvador. According to Bencastro, "Once Upon a River" is based on the Sumpul River massacre of 14 May1980, the El Mozote massacre of 11 December 1981, and the El Calabozo massacre on the bank of Amatitán River on 22 August 1982 (The Tree of Life 106). In this section of the story, five subjects give their accounts of the massacre, which inevitably include descriptions of the river:

3. The English quotations are from Susan Giersbach Rascón's 1997translation. 
The river was full of cadavers which the current then began to carry downstream. (104)

[T] here were tombs of dead children all along the river. (103)

I saw that they drowned the children they didn't shoot. Others they threw into the air and shot them as they fell. Many adults who didn't know how to swim drowned because the river war deep that day. (103)

The testimonies in this section create a vivid sense of the physical violence that occurred during the above-mentioned massacres. By setting the slaughter at the river, Bencastro reflects the reality of the events at El Calabozo and El Río Sumpul, where, in both cases, hundreds of campesinos were murdered in and on the banks of rivers as they attempted to flee the persecution of the Salvadoran army.

In addition to the historical reasons for the river imagery in "Once Upon a River," in the final two fragments of the story, which follow the testimonial section, Bencastro avails himself of the rich literary potential of the river by returning to it many years after the massacre. A man on horseback who has become lost in the valley comes across the river after three days of hunger and thirst, but is surprised by what he finds: "Voices emanated from the water, singing the tragedy of hundreds of unfortunate souls who once inhabited that region, and one ill-fated day, fleeing from persecution, threw themselves into the river where they died riddled with bullets" (105). Shocked and saddened by the river's story, the rider refuses to drink its water, preferring to die of thirst instead. Similar to Innocent Voices, the river has become a deathscape in the sense of a place associated with death and mourning and with deep symbolic meaning. Moreover, the image of the river as a speaking wound in this passage is an excellent example of Cathy Caruth's articulation of trauma narrative as the voice of the wound. That is, trauma not only as "the story of the individual in relation to the events of his own past, but as the story of the way in which one's own trauma is tied up with the trauma of another, the way in which trauma may lead, therefore, to the encounter with another, through the very possibility and surprise of listening to another's wound" (1996: 8). 
In "Once Upon a River" the testimonies of multiple subjects and the image of various voices emanating from the river create the effect of a collective wound among the Salvadoran people. The rider's decision not to drink the water can be understood as an act of solidarity that acknowledges that his life cannot be separated from the suffering of his fellow citizens.

Despite the river's association with death throughout the majority of the story and the horrific imagery of the testimonial section of the text, Bencastro concludes with a segment that restores the symbolism of the river to a source of life and nourishment: "The same waters that once were filled with blood and death became messengers of life and continued nourishing the valley with love and fantasy. Along its way flowers and trees again sprang forth, crops and animals flourished, families and towns expanded" (105). In doing so, he opens the possibility of renewed hope and refuses to allow El Salvador's rivers to be permanently converted into symbols of bloodshed. His conclusion suggests that if the river is a wound, then the wounds of trauma do not disappear, but can heal, and with healing comes the possibility of renewed life and hope. The shifting symbolism of the river in Bencastro's story is an excellent example of what Pettinaroli and Mutis characterize as the contradictory meanings of rivers in Latin American literature. That is, "as boundary and as connection; as paths to death and life; as emblems of both transformation and an anchoring of identity; as signs of dissolution and transformation; and as change and continuity (2013: 2).

\section{CLARIBEL ALEGRÍA'S "THE WOMAN OF THE SUMPUL RIVER"}

Similar to "Once Upon a River," Claribel Alegría's poem, "The Woman of the Sumpul River," was written as a denunciation of the Sumpul River massacre of 1980 that, as Mary K. DeShazer describes it, "saw more than six hundred campesinos fleeing El Salvador for their lives forced into the river to drown or be gunned down or hacked to death by Salvadoran or Honduran soldiers attacking them from each side of the border" (1994: 125). As a testimonial poem, "The Woman of the Sumpul River" inevitably portrays the river as the place where the killing occurred, but Alegría also takes advantage of the river's rich potential for symbolism 
in order to solicit the solidarity of the reader and more effectively capture the horror of the event. For Beverley and Zimmerman, "The Woman of the Sumpul River" is Alegria's "most powerful and influential effort" in creating "a poetized testimonio" in which the transcribed oral accounts of witness-participants in the war, in many cases, peasant women, are edited and rearranged in verse form" (1990: 138). The poem alternates between the first-person testimony of a mother who describes what she has experienced during the attack and the third-person narration of a separate poetic voice.

The opening verses of "The Woman of the Sumpul River" offer an invitation to the reader to accompany the poetic voice to the crater of a volcano where the history of El Salvador is churning. Here we find seminal figures from the pre-Columbian, colonial, independent, and modern eras, including Atlacatl, Pedro de Alvarado, Francisco Morazán, and Farabundo Martí. The opening image of the boiling caldera alludes to the country's social unrest and emphasizes the current moment of the civil war as yet another pivotal moment in Salvadoran history. The third-person poetic voice subsequently guides the reader down from the volcano into the countryside with all of its glimmering hues of green. As DeShazer astutely observes, the shades of green embodied in the fig trees, the ceiba trees, and the coffee groves in this section of the poem, symbolic of innocence and renewal, present a "harsh disjuncture characteristic of life in war-torn El Salvador" when contrasted with the buzzards and images of violence that pervade the text (1994: 125). Indeed, the image of "the buzzards / awaiting their feast" immediately precedes the first mention of the river in the poem, foreshadowing the association between the river and death that is subsequently established through the mother's testimony (20-21). ${ }^{4}$

After three of her children are murdered and her husband is captured, the mother falls wounded between two rocks at the river's edge. She plays dead and distracts her surviving child so as not to call the attention of the soldiers that sweep the area. The images of her innocent child as well as the five-year old who

4. The English quotations are from D.J. Flakoll's 1989 translation. 
asks her if he can get out of the water provide a stark contrast with the ruthless soldiers who mercilessly and indiscriminately murder men, women, and children as they attempt to escape across the river. As she lies with her child waiting for the danger to pass, the mother's body becomes inseparable from the earth: "her body mingling with the earth / and the leaves / is the earth / is the water / is the planet / mother earth" (70-76). Her wound thus becomes a wound in the earth: "wounded mother earth / look at that deep fissure / that gapes open / the wound is bleeding" (79-82). The images of the wounded Earth and the deep, bleeding, fissure evoke the image of the blood-stained river as wound, suggesting the possibility of the massacre as a collective trauma to the Salvadoran people and an aberration of nature.

The following verses, however, allow a second interpretation of the wounded Earth and the deep fissure by shifting the text's focus to the volcano as metaphor for a people in revolt: "the volcano spews lava / a raging lava / mingled with blood / our history / has turned into lava / into an incandescent people / mingling with the earth / into invisible guerrilleros" (83-90). These verses suggest that the Salvadoran people have erupted in resistance to the violence of a tyrannical regime in the form of the guerrilla movement. The image of the volcano as metaphor for social revolt calls to mind Max Horkheimer's notion of the "revolt of nature" in his seminal treatise Eclipse of Reason. For Horkheimer, reason in industrialized society is an instrument of domination that

Rivers of the Americas constantly forces individuals to repress their natural desires by conforming for the sake of self-preservation (Horkheimer 1992: 97, 105, 110). However, he argues, "resistance and revulsion arising from this repression of nature have beset civilization from its beginnings, in the form of social rebellions [...] as well as in the form of individual crime and mental derangement" (94). Nature, according to this perspective, is not an "other" that exists in opposition to humans, but rather a force that resides within us. Alegria's poem thus implies that the revolt of the people is not only justified, but, moreover, that it is a natural reaction that is indicative of their desire for freedom and justice.

In the poem's conclusion, after a lengthy list of the types of citizens (priests, beggars, guerillas etc.) that form the metaphorical 
lava of the people who burn for justice in the face of oppression, the mother appears before a reporter to tell her story. With one child in her arms and another walking at her side, this image fortifies the tone of hope and defiance that Alegría establishes throughout the poem. By concluding with a return to the beginning of the mother's testimony, "The Woman of the Sumpul River" reaffirms the importance of speaking of one's wounds both for the sake of historical truth and to resist the annihilation of one's identity (Laub 1995: 67, 70).

The image of the children as symbols of hope is consistent with the utopian vision of Alegria's poem as whole. With respect to the genre of Central American literature of testimony and resistance, Linda Craft has convincingly argued that "Ethics, urgency, and a utopian vision drive the witness/writer's production" (1997: 5). In this sense, "The Woman of the Sumpul River" parallels the other works analyzed in this essay. In Innocent Voices it is the construction of a world in which innocent children are no longer dragged into military conflicts and in "Once Upon a River" it is the belief in the possibility that El Salvador can heal from the wounds of civil war and that its people might one day lead a better, more peaceful life. This is achieved aesthetically in Bencastro's story by restoring the symbolism of the river to a source of life and nourishment, despite its tragic history.

In Innocent Voices, "Once Upon a River," and "The Woman of the Sumpul River," the traumatic events in the protagonists' lives that occur in and near rivers create an inversion of the conventional use of rivers as symbols of life, purity, innocence, and re-creation by associating them with violence, death, and destruction, revealing them as what Pettinaroli and Mutis refer to as "rivers of discontent" (2013: 14). At the same time, the river becomes a metaphor for the wounds of trauma, which allude to the psychological suffering not only of the protagonists, but to the collective pain of their countries torn asunder by war. Dennis Patrick Slattery has eloquently argued that wounds "always tell a story through their opening onto the world" (14). Without dishonoring the literal wounds that tens of thousands of victims suffered at the hands of their governments during the civil war in El Salvador, the works studied here make effective use of rivers as story-telling devices 
by establishing them as sites of historical atrocity and by aesthetically linking them with the wounds of the Salvadoran people to elicit the horror of this dark period in Central American history. Each of these works serves a testimonial function both in Laub's sense of a historical recovery that resists the annihilation of the victims' identities (1995: 67, 70) and in Linda Craft's sense as a protest that gives voice to the voiceless (1997: 15). For Laub, testimony as related to trauma is "a dialogical process of exploration and reconciliation of two worlds-the one that was brutally destroyed and the one that is-that are different and will always remain so" (1995: 74). In Innocent Voices, "Once Upon a River," and "The Woman of the Sumpul River" the image of the river as deathscape underscores the distance between these two worlds and allows each artist to make compelling contributions to the telling of Central American history. The traumatic events in the protagonists' lives that occur in and near rivers create an inversion of conventional use of rivers as symbols of life, purity, innocence, and re-creation by associating them with violence, death, and destruction.

GENOCIDE AND THE ENVIRONMENT IN ARTURO ARIAS'S THE PRICE OF COMFORT

Guatemalan author Arturo Arias's 2015 novel The Price of Comfort also sheds light on river-related violence from Central America's civil war period. Similar to El Salvador, during Guatemala's thirty-six-year war (1960-1996), the Guatemalan army engaged in a campaign of repression against labor unions, students, peasants, and indigenous citizens in an effort to dismantle leftist guerilla groups, which eventually united as the Guatemalan National Revolutionary Union (URNG) (Booth, et al. 2006: 121-123). The seeds of Guatemala's conflict were sown when democratically elected president Jacobo Arbenz Guzmán abruptly resigned in 1954 as the result of a military coup facilitated by the CIA in what was code-named "Operation PBSuccess." The Eisenhower administration had direct links to Guatemala's largest landowner the United Fruit Company, including Secretary of State John Foster Dulles, who represented United Fruit while he was a law partner at his New York law 
firm Sullivan \& Cromwell, and CIA Director Allen Dulles, who was a member of United Fruit's board of directors (Cohen 2012: 186). With the coup, the Eisenhower administration brought an end to Guatemala's decade of democracy and thwarted Arbenz's attempt at decolonial agrarian reforms intended to create a more just distribution of Guatemala's arable land.

The Price of Comfort reconstructs the history of several massacres that occurred between 1980 and 1982 along the Chixoy River (also known as the Río Negro above the Chixoy dam) in Guatemala. The slaughters came at the height of the civil war's violence, when "The army massacred numerous whole villages and committed many other atrocities against suspected guerilla sympathizers. [...] The counterinsurgency war made at least 500,000 persons, mostly Indians, into internal or external refugees" (Booth, et al. 2006: 123). As Barbara Rose Johnson explains,

the Río Negro massacres occurred in an area and at a time when Maya Achí communities were being forcibly displaced by construction of the Chixoy Dam funded by the World Bank and Inter-American Development Bank (IDB). Altogether, from 1980 to September 1982, some 447 residents of Río Negro-over half the population-were murdered in a series of four massacres that took place as dam construction was completed and flood waters began to rise. (2003: 27)

As the novel recounts, by the end of the dam's construction in 1983, ten communities had been destroyed by the massacres.

The history of the massacres is reconstructed throughout the novel as the protagonist, an expatriate reporter, recounts the story of his return to his native Guatemala on assignment to write an article about the Chixoy dam in Río Negro. The violence as a result of the dam project is gradually revealed through the protagonist's visits to the various massacre sites and interviews with survivors and local community members. The sporadic insertion of fragments of his completed article provides further context and historical details. The novel's historical component aligns with the observations of political ecologists that throughout Latin America, "Unequal distribution of water is due not only to colonial exclusion and historical usurpation of Indigenous communities' water rights, but also 
to contemporary policies," many of which focus on providing water and electricity for industries and mega-cities (Hidalgo, et al. 2017: 69).

As with Innocent Voices, "Once Upon a River," and "The Woman of the Sumpul River," the river becomes a deathscape in The Price of Comfort in the sense of a site associated with death, mourning, and memorial. In the Mayan communities that he visits, he reads the words from the memorial placards that mark the sites of the massacres. For example:

Here remains the memory of 54 native brothers and sisters of the Community of Chuategua, Pa Oj Chíi Ixim, Rabinal, Baja Verapaz, that were massacred on the 24th day of November, 1982, in the place named Piedra el Cal, this municipality. Those responsible for this massacre were the Guatemalan Army and the Rabinal Civil Self-Defense Patrol and the responsible parties enjoy their freedom. $(28-29)^{5}$

This passage and others, such as the wording on the memorial placard in Río Negro that he reads, serve as textual markers that resist attempts by national politicians to erase Guatemala's history of terror and genocide. Moreover, his visit to the Rabinal Achí Museum, with its room dedicated to memorializing victims of the massacres, further designates the river as a site of violence resulting from the neo-colonization of Mayan territory for the construction of the Chixoy dam. As the protagonist recalls, "It reminded me of the Holocaust museums that I visited in Washington and Houston" (46).

Rivers of the Americas

What distinguishes Arias's novel from the other works analyzed in the present article, however, is the portrayal not only of state sponsored violence at the site of a river, but also the environmental consequences wrought by the forceful imposition of a dam project on local indigenous communities. For example, a local citizen informs the protagonist of the effects of the dam on the river's ecosystem:

The river's water is very contaminated. The fish have worms, and you can't bathe in the river. The children have suffered from spots on their

5. This and subsequent English translations of passages from The Price of Comfort are translated by the author. The original Spanish has been included in footnotes where appropriate. 
skin because they go into the water. The river is really no good for anything, not even for washing. A little while ago they put in automatic gates. When it closes, a violent wave comes and then the poor people are stuck without water. They don't even warn us. (141) ${ }^{6}$

Moreover, adds the informant, the dam has caused an abundance of mosquitoes, which, in turn, has resulted in malarial infections (142). The bald hills surrounding the dam are further evidence of its environmental impact (40), and in the novel's concluding chapter the danger of anthropocentric thought is explicitly acknowledged in the reflections of one of the female indigenous characters, who laments, "Mistaken humans believe that they are the superior part of the chain of life, they think they are superior to animals and plants, and that's why they go about polluting so much, when in reality we are the lowest part, we are merely guardians of nature" (276).? The contrasting worldviews evident in this passage reflect the principles at the heart of the dispute over the construction of the dam.

The dam construction project is clearly cast in the novel as yet another cycle in Guatemala's history of colonization and neocolonization. Upon returning to Guatemala and interacting with Mayan ethnic groups for his reporting, the protagonist expresses his awareness of his country's colonial legacy when he is unable to follow conversations in one of the local Mayan dialects. He laments, "I felt the sharp pain of conquistadors emerging as if pulled by a soulless forceps" (34). ${ }^{8}$ Elsewhere in the novel he acknowledges being moved by the experience of standing in the place where the last Kaqchikel kings walked before being murdered by the conquistador Pedro de Alvarado (176). Moreover,

6. "El agua del río está bien contaminada. Los pescados tienen gusanos, y no se puede bañar. Los niños han padecido de muchas manchas porque se van a meter al agua. El río en verdad no sirve, ni para lavar. Hace poco pusieron unas puertas automáticas. Entonces se cierra se viene un tumbo, y de allí las pobres personas se quedan sin agua. Nosotros nada, sin avisarnos" (141).

7. "Los humanos tan equivocados creen que son la parte superior de la cadena de vida, se creen más que los animales, que las plantas, y por eso andan contaminando tanto, cuando en realidad somos la parte más baja, somos apenas los guardianes de la naturaleza [...]" (276).

8. "Sentí un dolor cortante de conquistadores emergiendo como jalado por un fórceps desangelado" (34) 
the text's allusion to Don Juan Matalab'atz, described as the first Mayan to go before the Spanish court in the sixteenth century, and who refused to kneel before the king, offers both a glimpse of the long history of Mayan resistance to colonial powers as well as a parallel to contemporary dynamics regarding access to land and natural resources. Doña Catarina, an indigenous leader who is raped in an attempt to suppress her activism, articulates the ways in which neocolonial modernization projects are destructive both environmentally and culturally:

We don't want them to harm the land [...] Without land we are nothing The land is our mother, our community, our life. We want our land back because it is ours, not the company's. As women, we are worried. The government wants to allow hydroelectric plants and the mining industry to steal our natural resources. How is it possible that the transnationals could come in and send us to the mountains again? $(118)^{9}$

This passage highlights the centrality of land in Mayan culture, both as a matter of subsistence and as a world view in which humans are not held as superior to other elements of the natural world. The loss of access to arable land and clean water thus becomes culturally as well as environmentally destructive. The "again" at the end of the passage emphasizes the cycles of colonization and neocolonization to which the Mayan people have been subjected

Rivers of the Americas since the Spanish Conquest. The neocolonial nature of the dam construction project is further underscored by the novel's mention of the fact that corporations from Switzerland, Mexico, US, Italy, Cermany, Japan, India, Portugal, and Canada participated in the process of the dam construction in spite of local resistance (26). Arias's novel thus fits well into what Laura Barbas Rhoden describes as Latin American fiction of "ecological imagination,"

9. No queremos que lastimen la tierra [...] Nosotras sin la tierra no somos nada. La tierra es nuestra madre, nuestra comunidad, nuestra vida. Queremos que regrese nuestra tierra, porque es de nosotras, no de la empresa, estamos preocupadas como mujeres. El gobierno quiere meter las hidroeléctricas, la minería, para robar nuestra riqueza natural. ¿Cómo es posible que vengan los transnacionales a mandarnos otra vez a la montaña? (118) 
which mobilizes a discourse of nature "to indict the neoliberal order of late twentieth-century Latin America" (2011: 2).

The description in the first chapter of the artificial lake created by the dam captures the oppressive nature of the project: "Carlos explained to me that at the bottom lay the flooded villages, the plantations of tomatoes, chili peppers, beans and corn now transformed into mud. The pre-Hispanic ruins of rabinaleb' were also lost there. To the right was the dam's fall, brutal in its verticality" (Arias 2015: 43).10 The image of villages and pre-Hispanic ruins submerged beneath the artificial lake poignantly captures the suppression of the Mayan people as a result of the dam. The description of the dam as "brutal" further evokes the violence done to the ecosystem, its human inhabitants, and their culture. As one informant explains, the majority of the good land was flooded, forcing them to move to higher ground where the terrain is rockier and inarable (116). As the protagonist's article points out, the indifference and disrespect for the Mayan villagers was such that, despite promises from the National Institute of Electricity (INDE), those who survived the massacres were never compensated for their land or resettled as a result of their dislocation (26).

In spite of the death and destruction inflicted by the massacres and dam construction, the novel's concluding chapter leaves open the possibility of hope for the future through continued Mayan resistance. In particular, the text emphasizes the importance of indigenous women in the Mayan rights movement and suggests a need to break with the patriarchal patterns of Guatemala's past. The violence against women throughout the novel, including rape and femicide, reveals the relation between the exploitation of natural resources and the abuse of women that ecofeminists such as Sofía Kearns contend is endemic to patriarchal societies (2006: 115). This aspect of the novel deserves further critical attention beyond the parameters of the present essay, but it is consistent with Arias's recognition of the evolving role of women in traditionally patriarchal societies (1997: 32). The female narrator of the final

10. "Carlos me explicó que en su fondo yacían los pueblos inundados, las plantaciones de tomates, chiles, frijoles y maíz ahora transformadas en cieno. También se perdieron allí las ruinas prehispánicas de los rabinaleb'. Al lado derecho estaba la caída de la presa, brutal en su verticalidad" (43). 
chapter alludes to the ongoing decolonial struggle in Guatemala in her statement that, "Colonization is always colonization" (Arias 2015: 282). Nevertheless, she remains steadfast in her commitment to the Mayan struggle: "I believe in Mayan flourishment. In spite of the racial domination, in spite of the genocide, and of all of that, we continue to survive. To be an indigenous woman, for me, has always implied struggle, so I am at peace with it" (266)."1

BERTA CÁCERES'S STRUGGLE

FOR THE GUALCARQUE RIVER IN HONDURAS

The struggle for environmental justice in Central America with regard to river access continues today. Perhaps the most visible example concerns the Gualcarque River, which flows at the edge of a collection of thirteen subsistence farming communities in the department of Intibucá, a predominantly indigenous region in southwestern Honduras. According to Nina Lakhani in her book of investigative journalism, Who Killed Berta Cáceres: Dams, Death Squads, and an Indigenous Defender's Battle for the Planet, "The sacred river is a source of spiritual and physical nourishment for the Lenca people. It provides fish to eat, water for their animals to drink, traditional medicinal plants, and fun: with no electricity, let alone internet, the children flock to the river to play and swim. The communities live in harmony with the river and with each other. Or at least they used to" (2020: 12). As Lakhani explains, the Agua Zarca hydroelectric dam was illegally licensed by the neoliberal National Party in 2010 "as part of a package of dam concessions involving dozens of waterways across the country in the aftermath of the 2009 coup-orchestrated by the country's right wing business, religious, political and military elites to oust the democratically elected President Manuel Zelaya" (12). The legal requirement of formal consultation for projects on indigenous territory was ignored prior to the licensing and no proper environmental impact study was conducted (12).

Given the dire consequences of diverting the river away from the needs of the Río Blanco communities, Berta Cáceres,

11. "Yo creo en el florecimiento maya. A pesar de la dominación racial, a pesar del genocidio, de todo eso, seguimos sobreviviendo. Ser mujer indígena para mí siempre implicó lucha, así que yo tranquila" (266). 
a Lenca community activist, led the resistance to the illegal project. In 2015 she was awarded the prestigious Coldman Environmental Prize for her opposition to the Agua Zarca dam. She too framed the struggle as another cycle in the history of colonial and neocolonial oppression: "No one expected the Lenca people to stand up against this powerful monster, and yet we indigenous people have been resisting for over 520 years, ever since the Spanish invasion. Seventy million people were killed across the continent for our natural resources, and this colonialism isn't over. but we have power, compañeros, and that is why we still exist" (Lakhani 2020: 11). The year after accepting the Goldman Prize, on 2 March 2016 Cáceres was murdered in an attempt to silence her opposition. Although the historical context in Central America has shifted from the period of armed revolutionary conflict to the post-war era, the dynamic of state-sponsored violence against community activists has not disappeared. As Lakhani explains, "Today, security forces are still deployed to protect foreign and national business interests, but belligerent community leaders are tarnished as anti-development criminals and terrorists, rather than as leftist guerillas" (2020: 278).

\section{CONCLUSION}

The works analyzed in the present essay are examples of the importance of river imagery in Central American literature and film. Innocent Voices, "Once Upon a River," and "The Woman of the Sumpul River" call attention to rivers as sites of historical violence during El Salvador's civil war, which pitted the country's fascist government against a revolutionary movement to liberate the country and reform its neocolonial economic structure. The government's response was characterized by the creation of death squads within its US-backed military, massacres of unarmed campesinos, and the torture and disappearance of suspected FMLN sympathizers. In the Calabozo Massacre and the Sumpul River Massacre, rivers became ground zero in the government's attempt to suppress the resistance. As works inspired by extrajudicial killings in and on the banks of Salvadoran rivers, I have thus argued that the imagery of rivers in Innocent Voices, "Once Upon a River," and "The Woman of the Sumpul River" can be 
described as deathscapes and speaking wounds that, in certain instances, are also contrasted with their more conventional symbolism of life, recreation, and innocence. Guatemalan novelist Arturo Arias's The Price of Comfort also sheds light on river-related violence from Central America's civil war era. However, in contrast to the Salvadoran works analyzed in the first part of this article, through the example of the Chixoy Dam, Arias's novel also highlights the environmental consequences of the neo-colonization of indigenous natural resources. The massacres along the Chixoy River, although part of the Guatemalan government's broader genocide against the Mayan people, were carried out in an effort to pave the way for the construction of an internationally funded dam that has displaced local indigenous citizens and destroyed natural resources vital to their survival. In Honduras, Berta Cáceres's campaign to prevent the illegal construction of the Agua Zarca dam on the Gualcarque River is another example of indigenous struggles across Central America to retain access to ancestral natural resources. Her subsequent assassination is an indication of the high stakes of the battle that she framed as a continuation of indigenous resistance to colonialism. What remains constant throughout the works studied in this essay is their portrayal of rivers as historical sites of colonial contestation. 
Alegría, Claribel. "La mujer del río Sumpul." El Salvador: poesía rebelde. El Salvador Solidarity Campaign, 1983, pp. 17-21.

------. "The Woman of the Sumpul River." Woman of the River. Translated by D. J. Flakoll, U of Pittsburgh P, 1989.

Anderson, Mark D. “Treacherous Waters: Shipwrecked Landscapes and the Possibilities for Nationalistic Emplacement in Brazilian Representations of the Amazon." Troubled Waters: Rivers in Latin American Imagination. Hispanic Issues On Line, vol. 12, 2013, pp. 111-126. https://hdl.handle.net/11299/184419

Arias, Arturo. "An Interview with Arturo Arias." By Cheryl Roberts. Speaking of the Short Story, edited by Farhat Iftekharuddin, et al. UP of Mississippi, 1997.

------. El precio del consuelo. F\&G Editores, 2015.

Barbas Rhoden, Laura. Ecological Imaginations in Latin American Fiction. UP of Florida, 2011.

Bencastro, Mario. "Había una vez un río." Árbol de la vida: historias de la guerra civil. Arte Público, 1997, pp. 75-111.

------. "Once Upon a River." The Tree of Life: Stories of Civil War. Translated by Susan Giersbach Rascón, Arte Público, 1997.

Beverley, John and Marc Zimmerman. Literature and Politics in the Central American Revolutions. U of Texas P, 1990.

Booth, John A., et al. Understanding Central America: Global Forces, Rebellion, and Change. $4^{\text {th }}$ ed., Westview, 2006.

Caruth, Cathy, editor. Trauma: Explorations in Memory. Johns Hopkins UP, 1995.

Caruth, Cathy. Unclaimed Experience: Trauma, Narrative, and History. Johns Hopkins UP, 1996.

Caso, Nicole. Practicing Memory in Central American Literature. Palgrave Macmillan, 2010.

Cohen, Richard. The Fish that Ate the Whale. Picador, 2012.

Craft, Linda. Novels of Testimony and Resistance from Central America. UP of Florida, 1997.

Cusack, Tricia. Riverscapes and National Identities. Syracuse UP, 2010. 
DeShazer, Mary K. A Poetics of Resistance: Women Writing in El Salvador, South Africa, and the United States. U of Michigan P, 1994.

Felman, Shoshana. "Education and Crisis, or the Vicissitudes of Teaching." Trauma: Explorations in Memory, edited by Cathy Caruth, Johns Hopkins UP, 1995, pp. 13-60.

Hidalgo, Juan Pablo, Rutgerd Boelens, Jeroen Vos. "De-colonizing Water: Dispossession, Water Insecurity, and Indigenous Claims for Resources, Authority, and Territory. Water History, vol. 9, 2017, pp. 67-85.

Horkheimer, Max. Eclipse of Reason. 1947. Continuum Publishing, 1992.

Johnson, Barbara Rose. "Reparations for Dam-Displaced Communities? The Legacy of Guatemala's Chixoy Dam." Anthropology News, Nov. 2003, pp 27-28.

Kane, Adrian Taylor. "Blood in the Water: Salvadoran Rivers of Testimony and Resistance." Troubled Waters: Rivers in Latin American Imagination. Hispanic Issues On Line, vol. 12, 2013, pp. 163-179. https://hdl.handle.net/11299/184416

Kearns, Sofía. "Nueva conciencia ecológica en algunos textos femeninos contemporáneos." Latin American Literary Review, vol. 34, no. 67, 2006, pp. 111-127. www.jstor.org/stable/20119966

Kressner, Ilka. “Counter (Current) Discourses: Rivers in William Ospina's Ursúa and El país de la canela." Troubled Waters: Rivers in Latin American Imagination. Hispanic Issues On Line, vol. 12, 2013, pp. 180-194. https://hdl.handle.net/11299/184415

Lakhani, Nina. Who Killed Berta Cáceres? Dams, Death Squads, and an Indigenous Defender's Battle for the Planet. Verso, 2020.

Laub, Dori. "Truth and Testimony: The Process and the Struggle." Trauma: Explorations in Memory, edited by Cathy Caruth, Johns Hopkins UP, 1995, pp. 61-75.

Maddrell, Avril and James D. Sidaway. Deathscapes: Spaces for Death, Dying, Mourning and Remembrance. Ashgate, 2010.

Mann, Iris. "Innocent Voices: Reliving El Salvador's Civil War." National Public Radio. 18 Oct. 2005. https://www.npr.org/templates/ story/story.php? storyld=4964460 
Marcone, Jorge. "Humboldt in the Orinoco and the Environmental Humanities."Troubled Waters: Rivers in Latin American Imagination. Hispanic Issues On Line, vol. 12, 2013, pp. 75-91. https://hdl.handle.net/11299/184421

Pettinaroli, Elizabeth and Ana María Mutis. Introduction. Troubled Waters: Rivers in Latin American Imagination. $U$ of Minnesota P. Hispanic Issues On Line vol. 12, Spring 2013, pp. 1-18. https://hdl.handle.net/11299/184426

Portela, M. Edurne. Displaced Memories: The Poetics of Trauma in Argentine Women's Writing. Bucknell UP, 2009.

Slattery, Dennis Patrick. The Wounded Body: Remembering the Markings of Flesh. Psychoanalysis and Culture. State $U$ of New York P, 2000.

Voces inocentes. Directed by Luis Mandoki, screenplay by Luis Mandoki and Óscar Orlando Torres. Twentieth Century Fox, 2004.

Torres, Oscar. Email interview conducted by Adrian Taylor Kane. 6 Sept. 2020.

------. "Oscar Torres Talk: University of Scranton Commemoration of UCA Martyrs." The U of Scranton, 14 Apr. 2015. https:// www.youtube.com/watch?v=mjJKYoEP23E 
